\title{
Kisspeptin-13 inhibits insulin secretion without affecting glucagon or somatostatin release: study in the perfused rat pancreas
}

\author{
R A Silvestre, E M Egido, R Hernández and J Marco \\ Hospital Universitario Puerta de Hierro and Department of Physiology, Medical School, Universidad Autónoma de Madrid, San Martín de Porres 4, 28035 \\ Madrid, Spain \\ (Correspondence should be addressed to R A Silvestre; Email: rsilvestre.hpth@salud.madrid.org)
}

\begin{abstract}
Kisspeptins are a family of peptides encoded by the KISS1 gene, which binds to G-protein-coupled receptor (GPR54), an orphan GPR54 related to galanin receptors. Endogenous forms composed of 54, 14, and 13 amino acids have been identified. Kisspeptin and GPR54 mRNAs have been detected in pancreatic B and A cells. Furthermore, kisspeptin-54 has been shown to slightly stimulate the last phase of glucose-induced insulin secretion in mouse and human islets and to inhibit insulin release in MIN6 cells. We have investigated the effect of kisspeptin-13 on insulin, glucagon, and somatostatin secretion. The study was performed in the perfused rat pancreas. Glucose, arginine, carbachol, and exendin-4 were used as secretagogues. Hormones were measured by RIA. Kisspeptin-13 reduced
\end{abstract}

glucose-induced insulin secretion in a dose-dependent manner $\left(\mathrm{IC}_{50}=1.2 \mathrm{nM}\right)$ and inhibited the insulin responses to both carbachol and exendin-4. Kisspeptin-13 blocked arginine-induced insulin secretion without affecting the glucagon or somatostatin responses to this amino acid, thus indicating that kisspeptin-13 influences B cells directly, rather than through an A- or D-cell paracrine effect. The reduction of the insulin response to exendin-4 induced by kisspeptin-13 was also observed in pertussis toxin-treated rats, thus suggesting an inhibition independent of $G_{i}$ proteins. In view of the potent insulinostatic effect of kisspeptin-13, it is tempting to speculate that kisspeptins may be implicated in the regulation of B-cell secretion.

Journal of Endocrinology (2008) 196, 283-290

\section{Introduction}

Kisspeptins are a family of peptides encoded by the KISS1 gene (Kotani et al. 2001, Muir et al. 2001, Ohtaki et al. 2001). KISS-1 was originally identified as a putative human metastasis suppressor gene in melanomas and breast cancer cells that acts without affecting tumorigenicity (Lee et al. 1996). Its expression has also been associated with antimetastatic activity in papillary thyroid (Ringel et al. 2002), esophageal (Ikeguchi et al. 2004), and bladder carcinoma (SánchezCarbayo et al. 2003).

The predicted KISS1 protein consists of 145 amino acids processed to a 54 amino acid peptide and subsequently amidated at the C-terminus. This peptide has recently been identified by three different groups as the endogenous ligand for an orphan G-protein receptor (GPR54; also known as AXOR-12; Kotani et al. 2001, Muir et al. 2001, Ohtaki et al. 2001) and was termed metastatin (Ohtaki et al. 2001) or kisspeptin (Kotani et al. 2001, Muir et al. 2001). Endogenous forms composed of 14 and 13 amino acids have also been identified (Kotani et al. 2001). Kisspeptin-10, the common C-terminal decapeptide shared by these forms, is the minimum sequence necessary for GPR 54 receptor activation
(Kotani et al. 2001, Muir et al. 2001) and is secreted by cultured human trophoblasts (Bilban et al. 2004).

GPR54 is an orphan G protein-coupled receptor structurally related to galanin receptors, originally cloned from rat brain (Lee et al. 1999). Tissue distribution of GPR 54 and its cognate ligand precursor, KISS1, often coincides. The levels of the transcripts of both are the highest in the placenta (Lee et al. 1996, Kotani et al. 2001, Ohtaki et al. 2001). Moreover, both KISS1 and GPR54 are widespread throughout the CNS (higher levels are reported in hypothalamus and pituitary; Lee et al. 1996). The hypothalamic KISS1/kisspeptin/GPR54 system has been shown to play a role as a major gatekeeper of gonadotropin-releasing hormone $(\mathrm{GnRH})$ neurons and the reproductive axis (Messager 2005, Castellano et al. 2006, Fernández-Fernández et al. 2006, Tena-Sempere 2006).

KISS1 is also expressed in peripheral tissue, testis, pancreas, liver, and small intestine, and kisspeptin receptor is highly expressed in pancreas, with lower expression in spleen, testis, peripheral blood lymphocytes, and adipose tissue (Kotani et al. 2001, Ohtaki et al. 2001, Harms et al. 2003).

Hauge-Evans et al. (2006) have recently demonstrated the presence of kisspeptin and GPR 54 mRNAs in both pancreatic B and A cells and GPR54 expression in MIN6 
and $\alpha$ TC1 pancreatic cell lines. Kisspeptin-54 has been shown to stimulate the late phase of glucose-induced insulin secretion in mouse and human islets and to inhibit insulin secretion from MIN6 cells.

To gain further insight into the effect of kisspeptin on islet cell secretion, we have investigated the effect of kisspeptin-13 on insulin, glucagon, and somatostatin secretion. The study was performed in the isolated perfused rat pancreas.

\section{Animals, materials, and methods}

\section{Animals}

Male Wistar rats (200-225 g body weight) from our inbred colony were used as donors. Animals were maintained in accordance with the guidelines established by the European Union (86/609). All experiments were performed between 0900 and $1200 \mathrm{~h}$. This is a period of minimal baseline feeding and activity for rodents. Rats had free access to food and water until they were used in the experiments. Feeding activity in rats shows a diurnal rhythmicity. Under ad libitum conditions, rats consume most of their food during the dark phase, in which feeding activity is bimodal, with peaks at the beginning (dusk feeding peak) and toward the end (dawn feeding peak) of the night (Meguid et al. 1992, Varma et al. 1999).

\section{Experimental protocol}

Each rat was anesthetized with sodium pentobarbital (50 mg/kg, i.p.), after which the pancreas was dissected and perfused in situ, as previously described (Silvestre et al. 1986). Effluent samples were collected from the portal vein, without recycling, at $1-\mathrm{min}$ intervals (flow rate, $2 \mathrm{ml} / \mathrm{min}$ ), and frozen at $-20{ }^{\circ} \mathrm{C}$ until the time of assay. The perfusion medium consisted of a Krebs-Henseleit buffer: $115 \mathrm{mM} \mathrm{NaCl}, 4.7 \mathrm{mM}$ $\mathrm{KCl}, 2 \cdot 6 \mathrm{mM} \mathrm{CaCl}_{2}, 1 \cdot 19 \mathrm{mM} \mathrm{H}_{2} \mathrm{HPO}_{4}, 1 \cdot 19 \mathrm{mM} \mathrm{MgSO}_{4}$ $7 \mathrm{H}_{2} \mathrm{O}$, and $24.9 \mathrm{mM} \mathrm{HNaCO}_{3}$ (gas phase 95:5, $\mathrm{O}_{2}: \mathrm{CO}_{2}$; pH 7·4), supplemented with 4\% (w/v) dextran T-70 (Pharmacia LKB Biotechnology, Uppsala, Sweden), 0.5\% (w/v) Cohn fraction $\mathrm{V}$ bovine albumin (Sigma-Aldrich), and glucose (5.5 mM; Sigma-Aldrich). Kisspeptin-13 was purchased from Bachem AC (Switzerland) and tested at graded concentrations (1 $\mu \mathrm{M}, 100 \mathrm{nM}, 10 \mathrm{nM}, 1 \mathrm{nM}$, and $0 \cdot 1 \mathrm{nM})$.

All substances studied were dissolved in $0.9 \% \mathrm{NaCl}$ containing $0 \cdot 1 \%$ BSA (Cohn Fraction V, Sigma-Aldrich). These solutions were prepared daily, immediately before experiments.

After a 35-min equilibration period, baseline samples were collected for $5 \mathrm{~min}$ and, at zero time, kisspeptin-13 was infused through a sidearm cannula. Stimulation of hormone secretion was induced by increasing the perfusate glucose concentration from 5.5 to $9 \mathrm{mM}$ and by infusing $10 \mathrm{mM}$ arginine, $10 \mu \mathrm{M}$ carbachol, or $1 \mathrm{nM}$ exendin-4. The sequence of addition of compounds to the perfusate is indicated in the corresponding figures. In control experiments, an identical volume of buffer was infused.

\section{Pertussis toxin treatment}

Treatment with pertussis toxin (PTX) from Bordetella pertussis (Sigma-Aldrich) was performed by injecting a single dose (3 $\mu \mathrm{g} / 100 \mathrm{~g}$ b.w., i.p.) 3 days before perfusions. This PTX treatment has been found to effectively ADP-rybosylate and inactivate $\mathrm{G}_{\mathrm{i}}$-protein coupled to adenylate cyclase (Ui et al. 1984, Komatsu et al. 1994, Silvestre et al. 1994, Egido et al. 2007). Control rats were subjected to a sham treatment consisting of injection of the corresponding buffer $(50 \%$ glycerol, 0.5 M NaCl, 0·05 M Tris-glycine, $\mathrm{pH} \mathrm{7 \cdot 5).}$

\section{Hormone determination}

Insulin, glucagon, and somatostatin were analyzed by RIA using the charcoal separation method (Herbert et al. 1965, Faloona \& Unger 1974, Harris et al. 1978). Experiments were randomized and all samples for each series of experiments were analyzed within the same assay.

\section{Insulin}

Anti-pig insulin serum (I8510, Sigma-Aldrich) and rat insulin standards (Novo Nordisk, Bagsvaerd, Copenhagen, Denmark) were employed. The inter- and intra-assay variations were $5 \cdot 3$ and $4 \%$ respectively.

\section{Glucagon}

Anti-glucagon serum (30 K) was kindly donated by R H Unger (University of Texas, Health Sciences Center, Dallas, TX, USA). The inter- and intra-assay variations were $6 \cdot 4$ and $4 \cdot 5 \%$ respectively.

\section{Somatostatin}

Anti-somatostatin serum (80C) was also donated by R H Unger (University of Texas, Health Sciences Center). The inter- and intra-assay variations were $5 \cdot 4$ and $4 \cdot 6 \%$ respectively.

\section{Statistical analysis}

Results are expressed as the mean \pm s.E.M. Insulin response was calculated as the integrated area of the curve above the mean preinfusion level (average of all the baseline levels for each perfusion) using the trapezoidal method. The normal distribution of our data was demonstrated by the Kolmogorov-Smirnov test (Siegel 1978). Differences between values were tested for significance by repeated-measures ANOVA in each group and by the unpaired Student's $t$-test.

\section{Results}

Figure 1 shows the effect of $1 \mu \mathrm{M}$ kisspeptin-13 on basal and on arginine-induced insulin (Fig. 1A), glucagon (Fig. 1B), 


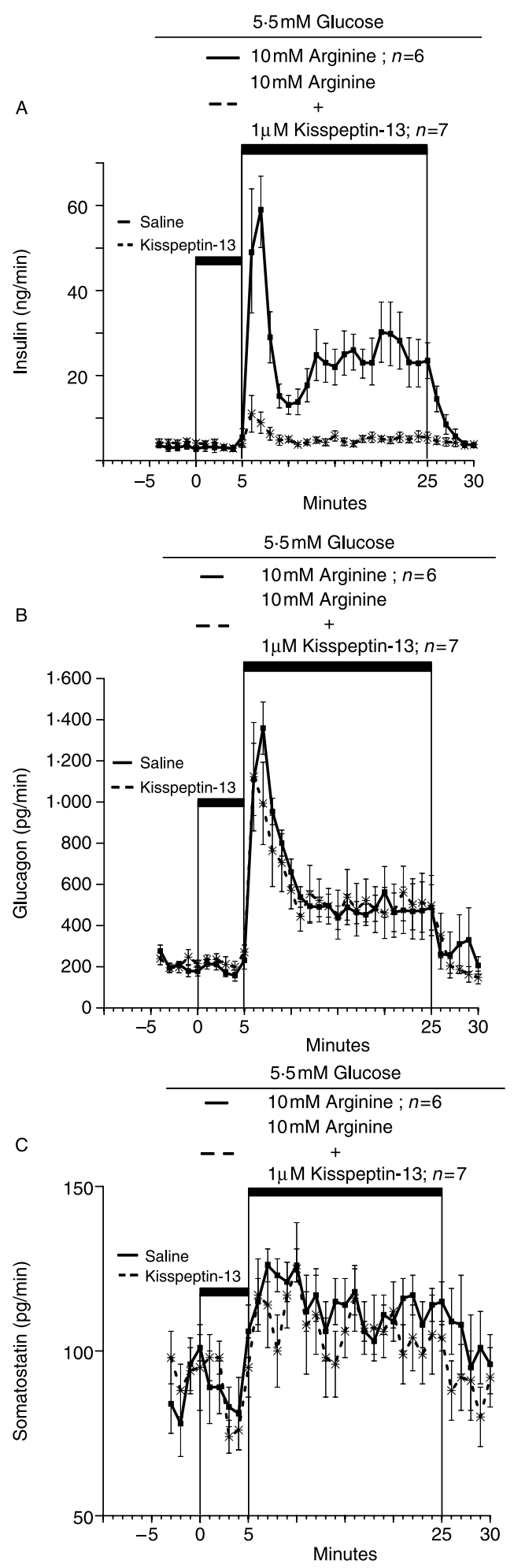

Figure 1 Effect of $1 \mu \mathrm{M}$ kisspeptin-13 on the (A) insulin, (B) glucagon, and $(\mathrm{C})$ somatostatin responses to $10 \mathrm{mM}$ arginine at $5.5 \mathrm{mM}$ glucose. Solid line $(n=6)$ : control, arginine alone. Broken line: arginine+ kisspeptin-13 $(n=7)$. Means \pm S.E.M. and somatostatin (Fig. 1C) secretion. Infusion of $1 \mu \mathrm{M}$ kisspeptin-13 did not significantly alter basal insulin, glucagon, or somatostatin secretion at a constant glucose concentration $(5.5 \mathrm{mM})$. At $1 \mu \mathrm{M}$, kisspeptin-13 blocked both phases of the arginine-induced insulin response (incremental areas: first phase: $14 \pm 7 \mathrm{ng} / 5 \mathrm{~min}$ versus $144 \pm 80 \mathrm{ng} / 5 \mathrm{~min}$ in controls; $P<0 \cdot 01$; second phase: $9 \cdot 4 \pm 11 \mathrm{ng} / 15 \mathrm{~min}$ versus $298 \pm 58 \mathrm{ng} / 15 \mathrm{~min}$ in controls; $P<0 \cdot 01)$ and did not significantly alter the glucagon or somatostatin responses elicited by this amino acid (incremental areas: $14 \pm 4 \mathrm{ng} / 20 \mathrm{~min}$ versus $15 \cdot 7 \pm 1.3 \mathrm{ng} / 20 \mathrm{~min}$ in control perfusions, $P=0 \cdot 757$; and $397 \pm 119 \mathrm{pg} / 20 \mathrm{~min}$ versus $479 \pm 106 \mathrm{pg} / 20 \mathrm{~min}$ in control perfusions, $P=0 \cdot 71$ respectively). Furthermore, ANOVA has demonstrated that basal insulin secretion was not affected by a prolonged (20 min) infusion of $1 \mu \mathrm{M}$ kisspeptin-13 (F=1.53; NS; data not shown).

Figure 2 shows the effect of graded concentrations of kisspeptin-13 on glucose-stimulated insulin secretion. As shown in Fig. 2A, infusion of kisspeptin-13 at $1 \mu \mathrm{M}$ did not significantly alter basal insulin secretion at a constant glucose concentration $(5.5 \mathrm{mM})$, but suppressed both phases of the insulin response induced by increasing the perfusate glucose concentration from 5.5 to $9 \mathrm{mM}$ (incremental areas: first phase: $-1.7 \pm 1.7 \mathrm{ng} / 5 \mathrm{~min}$ versus $41.6 \pm 5.1 \mathrm{ng} / 5 \mathrm{~min}$ in controls; $P<0 \cdot 01$; second phase: $0 \cdot 1 \pm 5 \cdot 8 \mathrm{ng} / 15 \mathrm{~min}$ versus $103 \pm 27 \mathrm{ng} / 15 \mathrm{~min}$ in controls; $P<0 \cdot 01)$. The insulin response to glucose observed in control perfusions (incremental area: $145 \pm 32 \mathrm{ng} / 20 \mathrm{~min}$ ) was significantly inhibited by kisspeptin-13 at $100 \mathrm{nM}$ (incremental areas: $4 \cdot 2 \pm 8 \mathrm{ng}$ / $20 \mathrm{~min} ; P<0 \cdot 01$; Fig. $2 \mathrm{~B}$ ) and at $10 \mathrm{nM}$ (incremental areas: $38 \pm 16 \mathrm{ng} / 20 \mathrm{~min} ; P<0 \cdot 025$; Fig. 2C). At $1 \mathrm{nM}$, kisspeptin-13 reduced glucose-induced insulin secretion (incremental area: $77 \pm 28 \mathrm{ng} / 20 \mathrm{~min}$ ), although the difference was not statistically significant (Fig. 2D). At $0 \cdot 1 \mathrm{nM}$, kisspeptin-13 did not significantly affect glucose-induced insulin secretion (incremental areas: $151 \pm 63 \mathrm{ng} / 20 \mathrm{~min}$ versus $145 \pm 33 \mathrm{ng}$ / $20 \mathrm{~min}$ in controls; $P=0.918$; Fig. 2E). The dose-response curve was fitted to a sigmoidal curve $\left(R^{2}=0.99\right)$ with an $\mathrm{IC}_{50}$ of $1 \cdot 2 \mathrm{nM}$ (Fig. 3).

Figure 4 shows that infusion of kisspeptin-13 at $10 \mathrm{nM}$ inhibited the insulin response to $10 \mu \mathrm{M}$ carbachol (incremental areas: $124 \pm 24 \mathrm{ng} / 20 \mathrm{~min}$ versus $465 \pm 85 \mathrm{ng} / 20 \mathrm{~min}$; $P<0 \cdot 01)$.

Finally, we examined the effect of kisspeptin-13 on the insulin response to exendin-4 both in PTX-treated and untreated rats (Fig. 5). As shown in Fig. 5A, in pancreases isolated from untreated rats, infusion of $10 \mathrm{nM}$ kisspeptin-13 blocked the insulin response to exendin-4 (incremental areas: $19 \pm 6 \cdot 7 \mathrm{ng} / 15 \mathrm{~min}$ versus $80 \pm 19 \mathrm{ng} / 15 \mathrm{~min}$ in controls; $P<0 \cdot 05)$. The inhibitory effect of kisspeptin-13 on the insulin response to exendin-4 was also observed in pancreases from PTX-treated rats (incremental areas: $15 \pm 8.7 \mathrm{ng} /$ $15 \mathrm{~min}$ versus $88 \pm 13 \mathrm{ng} / 15 \mathrm{~min}$ in controls; $P<0 \cdot 05$; Fig. 5B). 


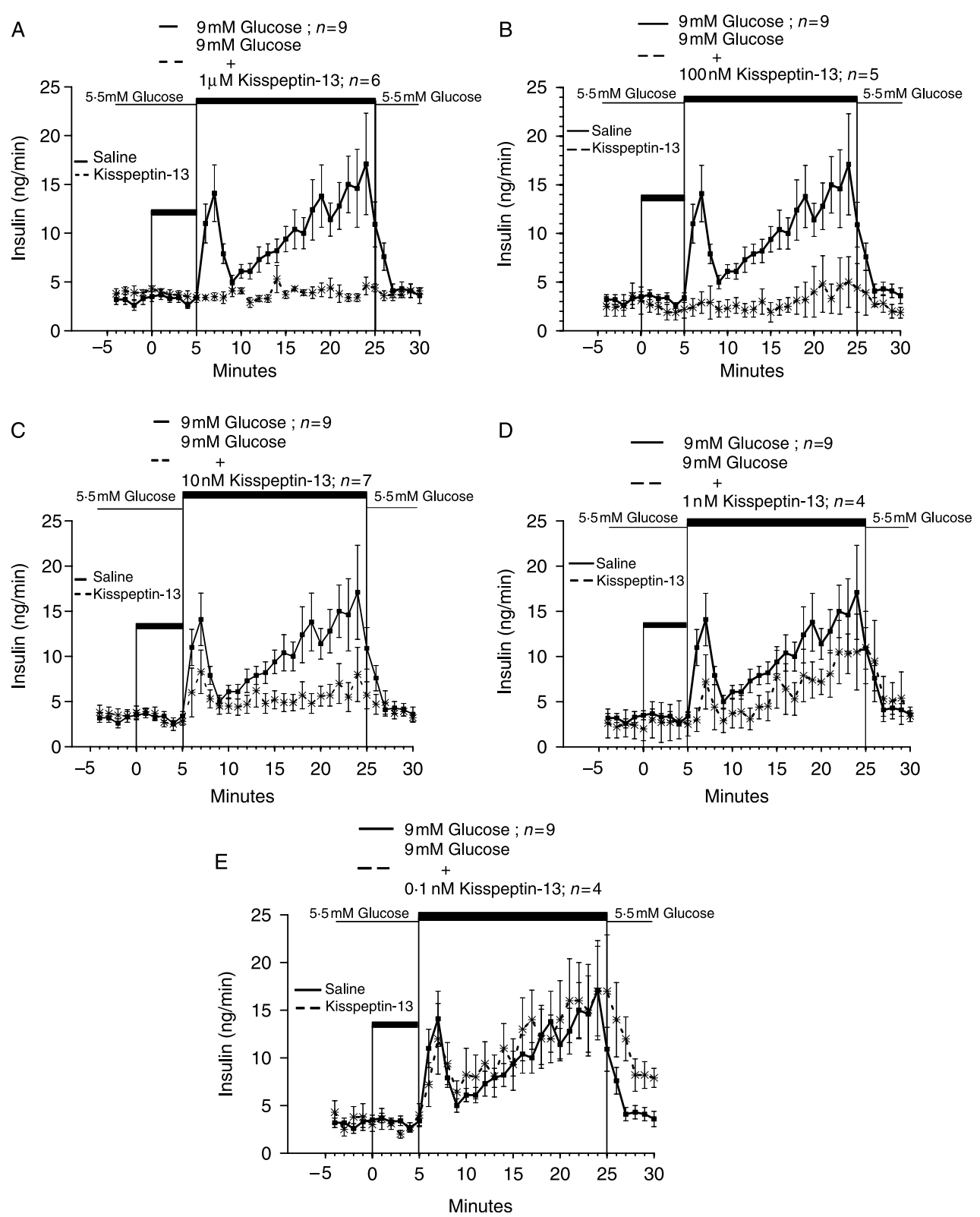

Figure 2 Effect of graded doses of kisspeptin-13 on the insulin response to glucose. Solid line ( $n=9)$ : control, glucose alone. Broken line: glucose + kisspeptin-13. (A) $1 \mu \mathrm{M}$ kisspeptin-13 $(n=6)$. (B) $100 \mathrm{nM}$ kisspeptin-13 $(n=5)$. (C) $10 \mathrm{nM}$ kisspeptin-13 $(n=7)$. (D) $1 \mathrm{nM}$ kisspeptin-13 $(n=4)$. (E) $0 \cdot 1 \mathrm{nM}$ kisspeptin-13 $(n=4)$.

Means \pm s.E.M.

\section{Discussion}

The foregoing results demonstrate that, in pancreases isolated from normal rats, infusion of kisspeptin-13 dose dependently inhibits glucose-induced insulin secretion. This inhibitory effect of kisspeptin-13 was observed when insulin secretion was stimulated by an increase in the perfusate glucose concentration (from 5.5 to $9 \mathrm{mM}$ ), resembling that occurring in normal subjects upon consuming a carbohydrate-rich meal; however, no effect of kisspeptin13 on basal insulin secretion was observed (with constant infusion of $5.5 \mathrm{mM}$ glucose).

Hauge-Evans et al. (2006) have recently shown that $1 \mu \mathrm{M}$ kisspeptin induced a slight, but significant, inhibitory effect on insulin secretion from MIN6 cells, while it potentiated the late phase of glucose-induced insulin secretion from mouse and human perifused islets. The discrepancy between our findings and those of the above-mentioned authors may be due to the 


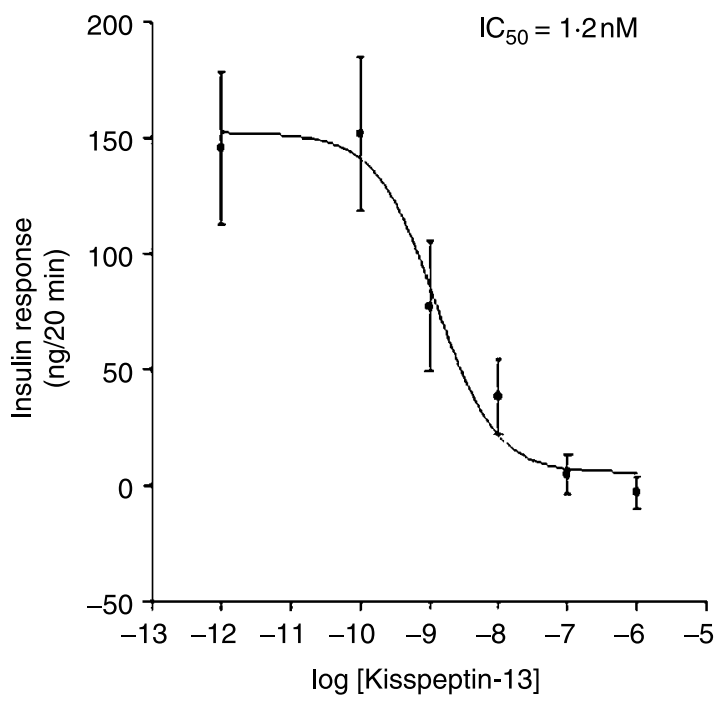

Figure 3 Dose-response curve corresponding to the inhibitory effect of kisspeptin-13 on the glucose-induced insulin response in the perfused rat pancreas. Hormone responses were calculated as the incremental areas under the curve. Means \pm s.E.M.

different experimental protocols employed in these investigations. The isolated rat pancreas may be more sensitive to several secretagogues and inhibitors of insulin secretion than islets obtained by collagenase digestion of the pancreas. On the other hand, in the present study, we have employed kisspeptin13, the C-terminal fragment of kisspeptin, a fact that might also explain the discrepancies observed with regard to the reported effect of kisspeptin on glucose-induced insulin secretion. Concerning this point, it should be pointed out that, in cells

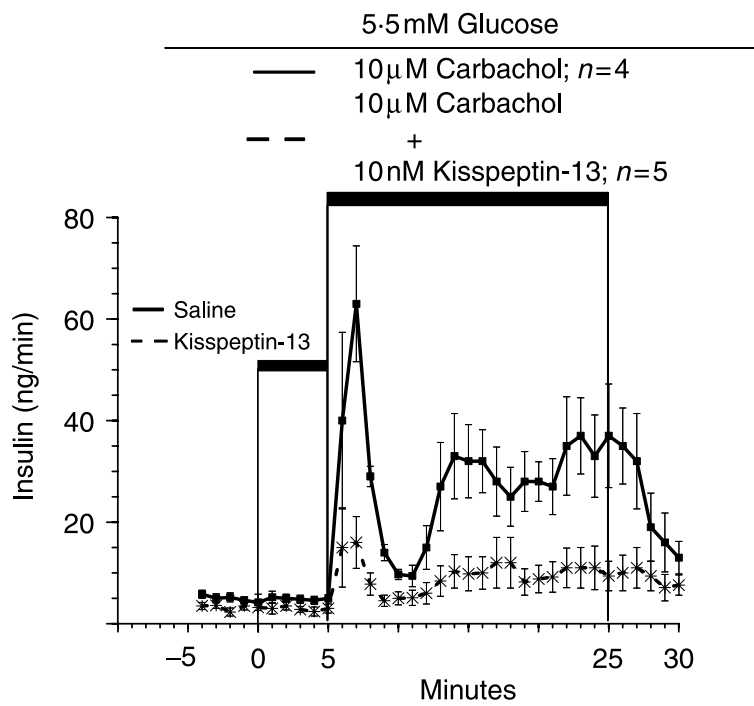

Figure 4 Effect of $10 \mathrm{nM}$ kisspeptin-13 on the insulin response to $10 \mu \mathrm{M}$ carbachol at $5.5 \mathrm{mM}$ glucose. Solid line $(n=4)$ : control, carbachol alone. Broken line $(n=5)$ : carbachol + kisspeptin-13. Means \pm S.E.M.
A

$5.5 \mathrm{mM}$ Glucose

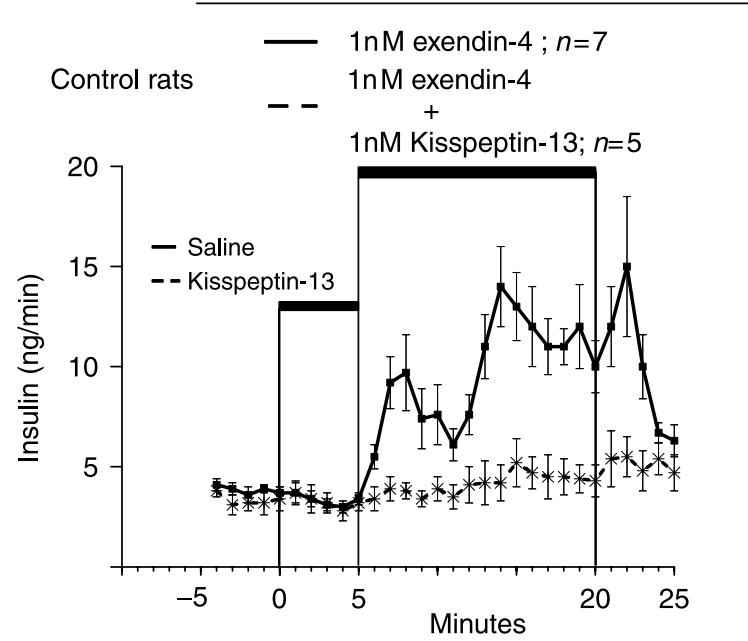

B $5.5 \mathrm{mM}$ Glucose

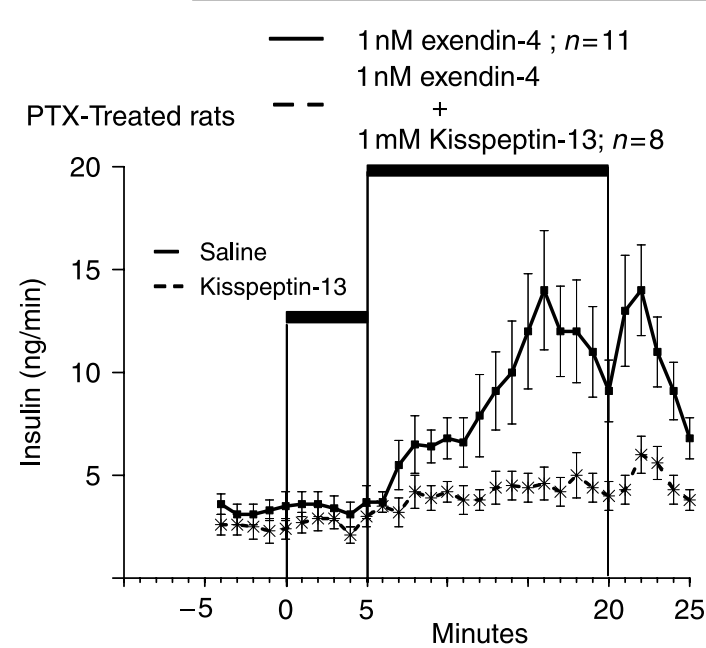

Figure 5 Effect of $10 \mathrm{nM}$ kisspeptin-13 on the insulin response to $1 \mathrm{nM}$ exendin- 4 at $5.5 \mathrm{mM}$ glucose. (A) Control rats. Solid line $(n=7)$ : control, exendin-4 alone. Broken line $(n=5)$ : exendin-4+ kisspeptin-13. (B) PTX-treated rats. Solid line $(n=11)$ : control, exendin-4 alone. Broken line $(n=8)$ : exendin-4+kisspeptin-13. Means \pm S.E.M.

overexpressing GPR54, all kisspeptin fragments have been found to have a similar affinity and efficacy for this receptor, thus indicating that the C-terminal portion of the kisspeptin molecule is responsible for the activation of GPR 54 (Kotani et al. 2001). However, other studies have found that kisspeptin-54 shows lower agonistic potency toward AXOR-12/GPR54 than kisspeptin-13 (Muir et al. 2001).

In our experimental model, the insulinostatic effect of kisspeptin-13 on glucose-induced insulin secretion is dose dependent, and the $\mathrm{IC}_{50}(1.2 \mathrm{nM})$ is comparable with the $\mathrm{EC}_{50}$ value $(1.38 \mathrm{nM})$ reported for binding of kisspeptin-13 
to rat GPR54 (Kotani et al. 2001). The inhibition of insulin secretion by kisspeptin-13 in the nanomolar range resembles the effect induced by other insulinostatic peptides - galanin (Sharp et al. 1989, Drews et al. 1994), somatostatin (Schuit et al. 1989), and 26RFa (Egido et al. 2007).

Kisspeptin-13 has been detected in peripheral plasma (Horikoshi et al. 2003, Panidis et al. 2006), where its levels correlate negatively with fasting plasma insulin levels (Panidis et al. 2006). Plasma kisspeptin concentrations are in the picomolar range, much lower than the concentrations employed in this study. However, kisspeptin has also been found in the pancreas (Kotani et al. 2001, Harms et al. 2003, Masui et al. 2004), and it can be assumed that in addition to the kisspeptin reaching the $\mathrm{B}$ cell through the systemic circulation, the local production of this peptide would augment its intra-islet concentration. Interestingly, plasma kisspeptin levels are dramatically elevated during pregnancy (up to 7000-fold higher than the normal value). This increase is in accord with the progression of pregnancy and seems to be related to the placental production of this family of peptides (Horikoshi et al. 2003).

The precise mechanism of action by which kisspeptin-13 could reduce B-cell secretory activity is not known. We have found that, besides reducing glucose-induced insulin secretion, kisspeptin-13 inhibits the insulin response to secretagogues that act on the B cell via different mechanisms, i.e. arginine, which depolarizes the B cell (Flatt 2003), thus activating voltage-dependent $\mathrm{Ca}^{2+}$ channels; carbachol, which increases phospholipid turnover by activating phospholipase C (PLC; Zawalich 1996, Flatt 2003); and exendin-4, which activates the adenylate cyclase/cAMP system (Göke et al. 1993, Flatt 2003). These findings suggest that kisspeptin-13 might influence $B$ cells by affecting a common distal step in the insulin secretory mechanism.

Kisspeptins have been shown to be the endogenous ligands for a heptahelical GPR 54; Kotani et al. 2001, Muir et al. 2001, Ohtaki et al. 2001), which is found in the pancreas (Kotani et al. 2001, Masui et al. 2004). GPR 54 mRNA expression has been detected in the MIN6 mouse insulinoma cell line and in the $\alpha$ TC1 mouse glucagon-secreting cell line (Hauge-Evans et al. 2006). Immunoreactive GPR54 was also found in human and mouse pancreatic islets with little or no immunoreactivity in the surrounding exocrine pancreas (Hauge-Evans et al. 2006). Thus, kisspeptin-13 might block insulin release by interacting with GPR54 present in pancreatic B cells. GPR 54 couples primarily with $G_{\alpha q / 11}$ proteins, leading to PLC activation, phosphatidylinositol (PI) turnover, and increase in intracellular calcium and protein kinase C activity (Kotani et al. 2001, Muir et al. 2001, Ohtaki et al. 2001, Stafford et al. 2002, Becker et al. 2005). Activation of this pathway in the $\mathrm{B}$ cell is associated with an increase in insulin secretion, as has been reported for activation of muscarinic receptors by carbachol (Zawalich 1996, Gilon \& Henquin 2001, Flatt 2003), and thus it cannot explain the insulinostatic effect of kisspeptin-13 found in the present study.
We have observed that the inhibitory effect of kisspeptin-13 on the insulin response to exendin-4 is maintained in PTX-treated rats, thus indicating that the insulinostatic effect of kisspeptin-13 is independent of PTX-sensitive $G$ proteins. It should be mentioned that, in our perfused pancreas system, the same batch of PTX has been shown to be effective in preventing the inhibition of exendin-4-induced insulin secretion elicited by other insulinostatic peptides, such as 26RFa (Egido et al. 2007) or ghrelin (unpublished data).

We have found that kisspeptin-13, at a concentration that totally blocked insulin release $(1 \mu \mathrm{M})$, failed to significantly modify either basal or arginine-stimulated glucagon output. In agreement with this, Hauge-Evans et al. (2006) have shown that, at the same concentration, kisspeptin failed to significantly modify glucagon secretion in the presence of either 2 or $20 \mathrm{mM}$ glucose. The present study provides the first data on the effect of kisspeptin-13 on somatostatin release. The lack of effect of kisspeptin-13 on glucagon and somatostatin secretion would rule out the possibility that the insulinostatic effect of kisspeptin-13 be due to a paracrine mechanism mediated by A- or D-cell secretion.

Kisspeptins belong to a peptide family with a common Arg-Phe- $\mathrm{NH}_{2}$ motif at their C-terminal end, and collectively termed RFamide-related peptides (RFPs; Kotani et al. 2001). Interestingly, other RFamide peptides have been shown to reduce insulin secretion at micromolar concentrations (Sorenson et al. 1984, Fehmann et al. 1990). Recently, using our perfused pancreas model, we have found that $26 \mathrm{RFa}$, another RFamide peptide, behaves as a potent inhibitor of insulin secretion (Egido et al. 2007). The insulinostatic effect of 26RFa resembles that of kisspeptin-13. Both peptides dose dependently inhibited glucose-induced insulin secretion (with $\mathrm{IC}_{50}$ at the nanomolar level) and reduced the insulin responses to arginine and exendin-4, thus suggesting that RFamide peptides may play a role in the control of B-cell secretion.

\section{Conclusion}

In view of the potent insulinostatic effect of kisspeptin-13, it is tempting to speculate that the kisspeptin family may be implicated in the regulation of B-cell secretion. The lack of effect of kisspeptin-13 on both glucagon and somatostatin secretion would indicate that it influences the B cell directly, rather than through an A- or D-cell paracrine effect.

As for the pathological relevance of our findings, it can be hypothesized that, by impairing insulin secretion, elevation of plasma kisspeptins could constitute a diabetogenic condition. Given the massive elevation of circulating kisspeptins during pregnancy, gestational diabetes might represent one of these conditions, a point worthy of investigation. 


\section{Acknowledgements}

This work was supported by grants from the Ministerio de Educación y Ciencia (SAF 2005-00836), Fondo de Investigación Sanitaria (FIS), Instituto de Salud Carlos III, Ministerio de Sanidad (PI050606, PI051610), and the MMA (Investigación Médica) Foundation, Spain. E M E is a Postdoctoral Investigator from the FIB Hospital Universitario Puerta de Hierro and R $\mathrm{H}$ is a Postdoctoral Research Fellow from the MMA Foundation. The expert technical assistance of Ms Pilar García, Ms Begoña Samper, and Mr Luis A Montero is gratefully acknowledged. We thank Ms Martha Messman for her editorial help. The authors declare that there is no conflict of interest that would prejudice the impartiality of this scientific work.

\section{References}

Becker JA, Mirjolet JF \& Bernard J 2005 Activation of GPR54 promotes cell cycle arrest and apoptosis of human tumour cells through a specific transcriptional program not shared by other Gq-coupled receptors. Biochemical and Biophysical Research Communications 326 677-686.

Bilban M, Ghaffari-Tabrizi N, Hintermann E, Bauer S, Molzen S, Zoratti C, Malli R, Shabari A, Hiden U, Graier W et al. 2004 Kisspeptin-10, a KISS$1 /$ metastin-derived decapeptide, is a physiological invasion inhibitor of primary human trophoblasts. Journal of Cell Science 117 1319-1328.

Castellano JM, Navarro VM, Fernández-Fernández R, Castaño JP, Malagón MM, Aguilar E, Diéguez C, Magni P, Pinilla L \& Tena-Sempere M 2006 Ontogeny and mechanisms of action for the stimulatory effect of kisspeptin on gonadotropin-releasing hormone system of the rat. Molecular and Cellular Endocrinology 257-258 75-83.

Drews G, Debuyser A \& Henquin JC 1994 Significance of membrane repolarization and cyclic AMP changes in mouse pancreatic B-cells for the inhibition of insulin release by galanin. Molecular and Cellular Endocrinology 105 97-102.

Egido EM, Hernández R, Leprince J, Chartrel N, Vaudry H, Marco J \& Silvestre RA 2007 26RFa, a novel orexigenic neuropeptide, inhibits insulin secretion in the rat pancreas. Peptides 28 725-730.

Faloona GR \& Unger R 1974 Glucagon. In Methods of Hormone Radioimmunoassay, pp 317-330. Eds BM Jaffe \& HR Behrman. New York: Academic Press.

Fehmann HC, McGregor G, Weber V, Eissele R, Göke R, Göke B \& Arnold R 1990 The effect of two FMRFamide related peptides (A-18-F-amide and F-8-F-amide; 'morphine modulating peptides') on the endocrine and exocrine rat pancreas. Neuropeptides 17 87-92.

Fernández-Fernández R, Martini AC, Navarro VM, Castellano JM, Dieguez C, Aguilar E, Pinilla L \& Tena-Sempere M 2006 Novel signals for the integration of energy balance and reproduction. Molecular and Cellular Endocrinology 254-255 127-132.

Flatt R 2003 The hormonal and neural control of endocrine pancreatic function. In Textbook of Diabetes 1. 3rd ed. pp 11.1-11.21. Eds JC Pickup \& G Williams. London: Blackwell Publishing.

Gilon P \& Henquin JC 2001 Mechanisms and physiological significance of the cholinergic control of pancreatic beta-cell function. Endocrine Reviews 22 565-604.

Göke R, Fehmann HC \& Linn T 1993 Exendin-4 is a high potency agonist and truncated exendin-(9-39)-amide an antagonist at the glucagon-like peptide 1-(7-36)-amide receptor of insulin-secreting beta-cells. Journal of Biological Chemistry 268 19650-19655.

Harms JF, Welch DR \& Miele ME 2003 KISS1 metastasis suppression and emergent pathways. Clinical and Experimental Metastasis 20 11-18.
Harris V, Conlon JM, Srikant CB, McCorkle K, Schusdziarra V \& Unger RH 1978 Measurements of somatostatin-like immunoreactivity in plasma. Clinica Chimica Acta 87 275-283.

Hauge-Evans AC, Richardson CC, Milne HM, Christie MR, Persaud SJ \& Jones PM 2006 A role for kisspeptin in islet function. Diabetologia $492131-2135$.

Herbert V, Lau KS, Gottlieb CW \& Bleicher SJ 1965 Coated charcoal immunoassay of insulin. Journal of Clinical Endocrinology and Metabolism 25 1375-1384.

Horikoshi Y, Matsumoto H, Takatsu Y, Ohtaki T, Kitada C, Usuki S \& Fujino M 2003 Dramatic elevation of plasma metastin concentrations in human pregnancy: metastin as a novel placenta-derived hormone in humans. Journal of Clinical Endocrinology and Metabolism 88 914-919.

Ikeguchi M, Yamaguchi K \& Kaibara N 2004 Clinical significance of the loss of KISS-1 and orphan G-protein-coupled receptor (hOT7T175) gene expression in esophageal squamous cell carcinoma. Clinical Cancer Research 15 1379-1383.

Komatsu M, McDermott AM, Gillison SL \& Sharp GWG 1994 Time course of action of pertussis toxin to block the inhibition of stimulated insulin release by norepinephrine. Endocrinology 136 1857-1863.

Kotani M, Detheux M, Vandenbogaerde A, Communi D, Vanderwinden JM, Le Poul E, Brézillon S, Tyldesley R, Suarez-Huerta N, Vandeput F et al. 2001 The metastasis suppressor gene KiSS-1 encodes kisspeptins, the natural ligands of the orphan G protein-coupled receptor GPR54. Journal of Biological Chemistry 276 34631-34636.

Lee JH, Miele ME, Hicks DJ, Phillips KK, Trent JM, Weissman BE \& Welch DR 1996 KISS-1, a novel human malignant melanoma metastasis-suppressor gene. Journal of National Cancer Institute 88 1731-1737.

Lee DK, Nguyen T, O'Neill GP, Cheng R, Liu Y, Howard AD, Coulombe N, Tan CP, Tang-Nguyen AT, George SR et al. 1999 Discovery of a receptor related to the galanin receptors. FEBS Letters 446 103-107.

Masui T, Doi R, Mori T, Toyoda E, Koizumi M, Kami K, Ito D, Peiper SC, Broach JR, Oishi S et al. 2004 Metastin and its variant forms suppress migration of pancreatic cancer cells. Biochemical and Biophysical Research Communications 315 85-92.

Meguid MM, Yang Z-J, Ratto C, Meguid RA, Hitch DC, Kubota A \& Campos AC 1992 Dynamics of oral intake resumption after general anaesthesia and operation in rats. Physiology and Behavior 52 597-601.

Messager S 2005 Kisspeptin and its receptor: new gatekeepers of puberty. Journal of Neuroendocrinology 17 687-688.

Muir AI, Chamberlain L, Elshourbagy NA, Michalovich D, Moore DJ, Calamari A, Szekeres PG, Sarau HM, Chambers JK, Murdock P et al. 2001 AXOR12, a novel human $G$ protein-coupled receptor, activated by the peptide KISS-1. Journal of Biological Chemistry 276 28969-28975.

Ohtaki T, Shintani Y, Honda S, Matsumoto H, Hori A, Kanehashi K, Terao Y, Kumano S, Takatsu Y, Masuda Y et al. 2001 Metastasis suppressor gene KISS-1 encodes peptide ligand of a G-protein-coupled receptor. Nature 411 613-617.

Panidis D, Rousso D, Koliakos G, Kourtis A, Katsikis I, Farmakiotis D, Votsi E \& Diamanti-Kandarakis E 2006 Plasma metastin levels are negatively correlated with insulin resistance and free androgens in women with polycystic ovary syndrome. Fertility and Sterility 85 1778-1783.

Ringel MD, Hardy E, Bernet VJ, Burch HB, Schuppert F, Burman KD \& Saji M 2002 Metastin receptor is overexpressed in papillary thyroid cancer and activates MAP kinase in thyroid cancer cells. Journal of Clinical Endocrinology and Metabolism 87 2399-2402.

Sánchez-Carbayo M, Capodieci P \& Cordon-Cardo C 2003 Tumor suppressor role of KISS-1 in bladder cancer: loss of KISS-1 expression is associated with bladder cancer progression and clinical outcome. American Journal of Pathology 162 609-617.

Schuit FC, Derde MP \& Pipeleers DG 1989 Sensitivity of rat pancreatic A and B cells to somatostatin. Diabetologia 32 207-212.

Sharp GW, Marchand-Brustel YL, Yada T, Russo LL, Bliss CR, Cormont M, Monge L \& Obberghen EV 1989 Galanin can inhibit insulin release by a mechanism other than membrane hyperpolarization or inhibition of adenylate cyclase. Journal of Biological Chemistry 13 7302-7309.

Siegel S 1978 Non Parametric Statistic for the Behavioral Changes. New York: McGraw- Hill. 
Silvestre RA, Miralles P, Moreno P, Villanueva ML \& Marco J 1986 Somatostatin, insulin and glucagon secretion by the perfused pancreas from the cysteamine-treated rat. Biochemical and Biophysical Research Communications 134 1291-1297.

Silvestre RA, Salas M, García-Hermida O, Fontela T, Dégano P \& Marco J 1994 Amylin (islet amyloid polypeptide) inhibition of insulin release in the perfused rat páncreas: implication of the adenylate cyclase/cAMP system. Regulatory Peptides 50 193-199.

Sorenson RL, Sasek CA \& Elde RP 1984 Phe-met-arg-phe-amide (FMRF$\mathrm{NH}_{2}$ ) inhibits insulin and somatostatin secretion and anti-FMRF- $\mathrm{NH}_{2}$ sera detects pancreatic polypeptide cells in the rat islet. Peptides $\mathbf{5}$ 777-782.

Stafford LJ, Xia C, Ma W, Cai Y \& Lui M 2002 Identification and characterization of mouse metastasis-suppressor KISS1 and its G-proteincoupled receptor. Cancer Research 62 5399-5404.

Tena-Sempere M 2006 The roles of kisspeptins and G protein-coupled receptor54 in pubertal development. Current Opinion in Pediatrics 18 442-447.
Ui M, Katada T, Murayama T, Kurose H, Yajima M, Tamura M, Nakamura T \& Nogimori K 1984 Islet-activating protein, pertussis toxin: a specific uncoupler or receptor-mediated inhibition of adenylate cyclase. Advances in Cyclic Nucleotide and Protein Phosphorylation Research 17 145-151.

Varma M, Chai J-K, Meguid MM, Gleason JR \& Yang Z-J 1999 Effect of operative stress on food intake and feeding pattern in female rats. Nutrition 15 365-372.

Zawalich WS 1996 Regulation of insulin secretion by phosphoinositidespecific phospholipase C and protein kinase C activation. Diabetes Reviews 4 $160-176$.

Received in final form 19 October 2007

Accepted 8 November 2007

Made available online as an Accepted Preprint 8 November 2007 